UNIO - EU Law Journal. Vol. 4, No. 2, July 2018, pp 117-127.

®2018 Centre of Studies in European Union Law

School of Law - University of Minho

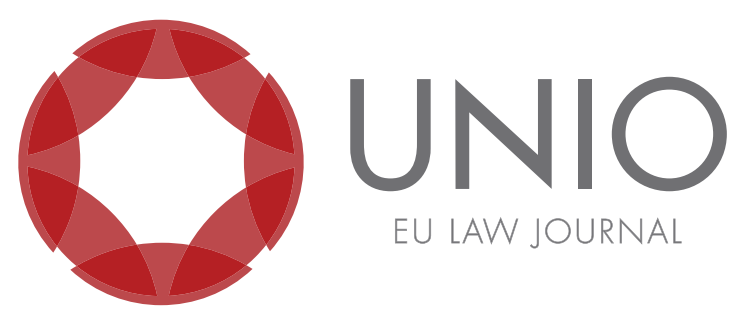

\title{
The cyberpolitical space of the European Union: an overview of e-Government, e-Democracy and interoperability in the European space and its citizenship
}

\author{
Rui Castro Vieira*
}

ABSTRACT: e-Government and e-Democracy, in the latest decades, with the recent fast-paced developments of information and communication technologies, have been regarded as new mechanisms to enrich the democratic culture and link institutions to its citizens. The European Union is a peculiar case with its own idiosyncratic form of citizenship. In this paper, we analyse the progresses of e-Democracy in the European Union and its developments through interoperability projects, as well as its challenges with the uprising, in the latest years, of many problems that came from the use of these technologies. We argue that a promotion of the European citizenship is necessary in the development of a European Union cyberspace.

KEYWORDS: e-Democracy - European citizenship - interoperability - Isa programme Digital Single Market.

\footnotetext{
* Master's student in EU Law at the University of Minho.
} 
UNIO - EU Law Journal. Vol. 4, No. 2, July 2018, pp 117-127.

®2018 Centre of Studies in European Union Law

School of Law - University of Minho

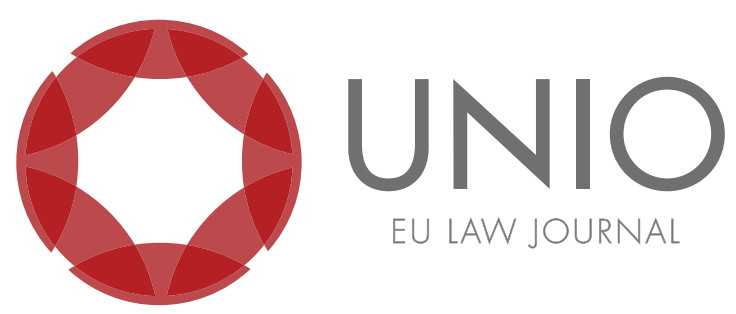

\title{
The Fyberpolitical space of the European Union: an overview of e Government, e-Democracy and interoperability in the European space and its citizenship
}

\author{
Rui Castro Vieira*
}

ABSTRACT: e-Government and e-Democracy, in the latest decades, with the recent fast-paced developments of information and communication technologies, have been regarded as new mechanisms to enrich the democratic culture and link institutions to its citizens. The European Union is a peculiar case with its own idiosyncratic form of citizenship. In this paper, we analyse the progresses of e-Democracy in the European Union and its developments through interoperability projects, as well as its challenges with the uprising, in the latest years, of many problems that came from the use of these technologies. We argue that a promotion of the European citizenship is necessary in the development of a European Union cyberspace.

KEYWORDS: HDemocracy - European citizenship - interoperability - Isa programme Digital Single Market.

\footnotetext{
* Master's student in EU Law at the University of Minho.
} 


\section{The development of the cyberpolitical initiatives: e-Government and e-Democracy ${ }^{1}$}

\subsection{The effect of the Internet on the democratic culture}

The relationship between political entities and its citizens throughout time has always been in a constant evolution, with communicational structures taking a major role on developing these interactions. ${ }^{2}$

Historically, communications infrastructure has played a crucial role in transmitting information and developing public opinion, as well as allowing public and democratic debate, freedom of speech. This always required ways of spreading in a political model of organization, from the printing, press, editors, reporters, bureaus, and in the last centuries to telecommunication infrastructures. More recently, these are, also, the way some control, regulation and even censorship made by the part of States, Administrations, and Institutions. ${ }^{3}$

The use of information is particularly important for the Public sphere, considering that the gap of information has proven to be a cause of distrust and dissatisfaction with the government and public institutions, being one of the main causes of the decline of public trust in the last decades. ${ }^{4}$

In the recent years, the Internet has taken the main role as an information mechanism for political communication, to the point of being the main tool political institutions address and communicate with their citizens. ${ }^{5}$

The Internet can be a powerful tool for democracy, considering the fact that it, itself, democratized process of accessing information, allowing anyone with proper Internet access, to connect to any information, allowing one to overcome barriers for that access to information, especially among different countries, institutions, and social groups, all at an instant speed. Worldwide, where there is access to the Internet, there is access to knowledge. There is also the fact that the Internet stimulates some transparency on the political debate and allows citizens to disseminate opinions and information regarding any issue, allowing ideas to clash and be debated. It is, therefore, the author's argument that the political-ideological argument has benefited from this free environment and the freedom of expression it allows. ${ }^{6}$

\footnotetext{
${ }^{1}$ This paper was selected amongst the essays presented to INTEROP Project researchers by the Master's students of the School of Law of the University of Minho in the last academic semester of 2017/2018 regarding the development of the Digital Single Market.

${ }^{2}$ See Lourdes Torres, Vicente Pina and Bacilio Acerete, "E-Governance Developments in European Union Cities: Reshaping Government's Relationship with Citizens", Governance: An International Journal of Policy, Administration and Institutions 19(2) (2006): 279. Ruth Wodak and Scott Wright, "The European Union in Cyberspace Multilingual Democratic Participation in a virtual public sphere?”, Journal of Language and Politics 5(2) (2006): 253.

${ }^{3}$ See Jack M. Balkin, “Old-School/New-School Speech Regulation”, Harvard Law Review 127 (2014): 2296-2306.

${ }^{4}$ See Eric W. Welch, Charles C. Hinnant, M. Jae Moon, "Linking Citizen Satisfaction with E-Government and Trust in Government", Journal of Public Administration Research and Theory 15(3) (2004): 371-372.

${ }^{5}$ Some of these problematics have arisen lately in the other side of the Atlantic, with American courts ruling that the United States of America President not being allowed to block users on online platforms, which end up becoming "public forums" in this context. See: https://www.bloomberg. com/news/articles/2018-05-23/trump-told-by-judge-not-to-block-users-from-his-twitter-feed.

${ }^{6}$ See Pedro Verdelho, "Democracia e tecnologias da informação", in UNIO/CONPEDI E-book 2017 Interconstitucionalidade: Democracia e Cidadania de Direitos na Sociedade Mundial - Atualização e Perspectivas Vol. II, coord. Alessandra Silveira (Braga: Centro de Estudos em Direito da União Europeia, 2018),
} 
Social Networks and online platforms have lead to the development of "community"-like forms of social interactions among online users, even if they tend to, often, be only an extension of the off-line life most users have. ${ }^{7}$ In any case, these online platforms have allowed what can be called the "networked public sphere". ${ }^{8}$

\section{2. e-Government and e-Democracy as the new developments on cyberpolitics}

With such rapid developments and social phenomena, there was a need and interest for government and public entities to streamline the public sphere and enhance its efficiency, a concern that already developed by the end of the last millennium, in order to increase citizens participation in democratic activities. The Anglo-Saxon countries (United States of America, United Kingdom, Canada, and Australia) pioneered in developing what was known as "e-government" and "e-governance" by the end of the last millennium. ${ }^{\text {" }}$

Despite the use of this expression ever since then for many years, the notion of "e-government" and the distinction of "e-governance" is not clear. Even the distinguishing of "government" from "governance" is not easy. "E-governance" has been defined as the use of ICT to support public services, democracy, the private sector, etc; Technology mediated services; Something that includes e-government; A model of government; A commitment to technology; Functions that empower citizens; Internally focused use of ICT by government; Use of ICT to improve the quality of services and governance; Something that enhances e-democracy; $A$ technology-mediated relationship between citizen and state, among many other definitions. ${ }^{10}$

The Organisation for Economic Cooperation and Development (hereinafter, OECD), in 2003, defined e-Government as the use of Informatic and Communication Technologies (hereinafter, ICT) and particularly the Internet, as a tool to achieve better government. ${ }^{11}$

National e-Government programmes had a major advance in 2001 with many countries starting to utilize the potential of the Internet to offer content-rich, welldesigned citizen-centric website pages. ${ }^{12}$

In any case, the basic ideas and notions involve the use of ICT to further develop the interactions and participation of citizens in the public sphere, therefore promoting their role on a form of "e-democracy", on a form of democratic participation and interaction between political and public bodies and their citizens, through an efficient use of information and communication technologies to promote this link between the public and governmental sphere and the people.

\section{0-112.}

${ }^{7}$ See Malcolm R. Parks, "Social Network Sites as Virtual Communities", in A Networked Self Identity, Community, and Culture on Social Network. Sites, Zizi Papacharissi, ed. (New York: Routledge, 2011), 105120.

${ }^{8}$ See Marvin Ammori, “The 'New' New York Times: Free Speech Lawyering in the age of google and Twitter”, Harvard Law Review 127 (2014): 2268.

${ }^{9}$ See Lourdes Torres, Vicente Pina and Bacilio Acerete, E-Governance Developments in European Union Cities..., 277, and Andrew Chadwick and Christopher May, "Interaction between States and Citizens in the Age of the Internet: "e-Government" in the United States, Britain, and the European Union", Governance: An International Journal of Policy, Administration, and Institutions 16(2) (2003): 272.

${ }^{10}$ See Frank Bannister, Regina Connoly, "Defining E-Governance", e-Service Journal 8(2) (2012): 9.

${ }^{11}$ See Lourdes Torres, Vicente Pina and Bacilio Acerete, E-Governance Developments in European Union Cities..., 278.

${ }^{12}$ See the 2002 U.N study, accessed on 02/06/2018, on: https:/ / publicadministration.un.org/egovkb/ portals/egovkb/documents/un/english.pdf. 
This new form of binding institutions with their citizens is meant to promote unmediated discussions, direct participation and representation and greater transparency and accountability through political openness. ${ }^{13}$ In a new free space where the citizens express their right to freedom, the Information and Communication Technologies offer new instruments where this personal freedom can be exercised. This right to freedom means not only the possibility of a new personal freedom, but also to control his/her own information concerning himself/herself ${ }^{14}$, although this is not such a simple right with the complex developments of some technologies.

That would mean that by citizens going online to communicate opinions or complaints to government related to a public issue, citizens would, therefore, join the democratic process by seeking to shape the next public policies, which would be an active participation in the democratic process, extending beyond simple information seeking on policy questions. ${ }^{15}$

The older and traditional representative democratic mechanisms have always had their flaws, with the bureaucracies created around it, leading to the feeling from citizens that are not represented at all. This has been seen throughout all the representative democracies around the world, where high levels of dissatisfaction are present. There are many statistical indicators that show a decline in the ability of the current democratic systems to involve citizens in Government. ${ }^{16}$ In this sense, the introduction of new mechanisms could fill up the void between democratic institutions and the citizens. After all, Time, Law and Society are linked together, in an institutional way ${ }^{17}$, and the reshaping of political-governance structures and methods, therefore, is a constant phenomenon. Post-Modernity can be characterized as a period beyond modernity when it goes beyond the flawed political systems, looking for more adaptations to the Human being. The need to go beyond the classical methods of democracy and governance without a rupture is one of the traits of this post-modern phenomenon in a political-institutional view. ${ }^{18}$

The development of an information society led to a liberating effect where these technologies could end up helping the common citizen to plan and shape his/ her decision in a fast-paced dynamic way. ${ }^{19}$

Furthermore, some advocate that these new forms of democratic participation could lead to newer forms of deliberative or direct democracy, with an easier way for direct decision-making. ${ }^{20}$

\footnotetext{
13 See Julie Freeman and Sharna Quirke, "Understanding E-Democracy", JeDEM - eJournal of eDemocracy and Open Government 5(2) (2013): 141.

${ }^{14}$ See Marina Pietrangelo, "E-government e società dell'informazione: la prima legge regionale", Informatica e diritto Rivista internazionale XII (2003): 149-150.

${ }^{15}$ See John Clayton Thomas and Gregory Streib, "E-Democracy, E-Commerce and E-Research: Examining the Electronic Ties Between Citizens and Governments", Administration \& Society 37(3) (2005): 261.

${ }^{16}$ For a deeper analysis see J.I. Pelaez, A.M Casado, Estrela R. Yanez, Freddy A. Duran, "E-Democracy \& E-Government: Present and Future", In 2016 Third International Conference on eDemocracy \& eGovernment (ICEDEG) Sangolqui, Ecuador, Luis Teran and Andreas Meier, ed. (New Jersey: Institute of Electrical and Electronics Engineers, Inc, 2016), 81-84.

${ }^{17}$ See Fabiana Spengler, “Tempo, direito e sociedade”, Lusíada II(6) (2008): 135.

${ }^{18}$ See Paulo Ferreira da Cunha, Pensar o Direito II: Da Modernidade à Postmodernidade (Coimbra: Almedina, 1991), 45-51.

${ }^{19}$ See Garcia Marques and Lourenço Martins, Direito da Informática (Coimbra: Almedina, 2000), 75-79.

${ }^{20}$ See Marianne Kneuer, "E-democracy: A new challenge for measuring democracy", International Political Science Review 37(5) (2016): 667.
} 
Democracy, ever since the end of the Cold War, has played an increasingly prominent role on the International level, being identified as critical to the promotion of human rights, as an essential factor in maintaining peace and stability between States. There is a tendency, already observed, for a growing global commitment to liberal democratic forms of government. Despite this growing importance, there have not been proper responses to the failures and dissatisfaction already mentioned and if we look at democracy as a purely procedural form, a failure of democracy is, therefore, an absence of such procedures and the proper response to this failure. ${ }^{21}$ The measures defended by e-Democracy would, therefore, be a way of making up for these procedural issues and flaws that hinder the democratic functioning.

Some of these measures include enhancing the political dimension on the Internet, the citizen dialogue and financial accountability. ${ }^{22}$ However, governments have mostly used their Information and Communication Technologies to disseminate information and deliver services, the focus being more on the efficiency of these technologies than their utility as a means to the effectiveness of democratic processes, which has led to forms of government centricity in e-Government policies and practices, which has resulted in some neglecting of online civic inclusion in political decision making. Interactivity between citizens and institutions is, therefore, restricted for governments to maintain control of communication. Information dissemination, in spite of its usefulness and need in a democratic society, provides little capacity for citizen involvement in government decision-making. ${ }^{23}$ The engagement of citizens in e-Democracy models has, therefore, been rather limited.

The notion of e-Democracy itself is a bit vague with some authors using it to encompass e-Government, e-participation, cyberpolitics, among many others, that broadness of the concept is one of the possible causes of the fact there have not been many developed citizen interactive models. International organizations like the United Nations and the OECD define a three-level approach. The United Nations distinguishes between e-information, e-consultation and e-decision-making. Although the OECD also uses a three-level approach, e-Government is subsumed under 'e-engagement' and includes e-information, e-consultation, and e-participation. Moreover, the OECD, in contrast to the United Nations, defines e-engagement as a two-directional mechanism (top-down and bottom-up). ${ }^{24}$

A big part of the investments for e-Government and e-Democracy have been channelled to e-administration and other services from what can be called a "services first and democracy later" approach to e-Government on a report by the OECD of 2003. Some of the problems surrounding the development of e-Democracy, using the citizens as a point of reference were identified. The problems reported were coping with the problem of scale; building capacity and active citizenship; ensuring coherence throughout the policy-making progress; evaluating the benefits and impacts of offering digital citizen engagement; and ensuring government commitment ${ }^{25}$.

\footnotetext{
${ }^{21}$ See Molly Beutz, "Functional Democracy: Responding to Failures of Accountability", Harvard International Law Journal 44(2) (2003): 387-388.

${ }^{22}$ See Lourdes Torres, Vicente Pina and Bacilio Acerete, E-Governance Developments in European Union Cities..., 286.

${ }^{23}$ See Julie Freeman and Sharna Quirke, Understanding E-Democracy..., 142.

${ }^{24}$ See Marianne Kneuer, E-democracy: A new challenge for measuring democracy..., 669.

${ }^{25}$ See Harald Mahrer and Robert Krimmer, "Towards the enhancement of e-democracy: identifying the notion of the 'middleman paradox"', Information Systems Journal 15 (2005): 31.
} 


\section{II. e-Government and e-Democracy on the European Union and its peculiarities}

\subsection{The European Union political cyberspace and citizenship}

The European Union is characterized for being a completely new form of political-institutional organization that goes beyond the classical forms of a nationstate. Some of the European Continent's uniqueness goes far back to the European project itself. A historical phenomenon on the European Continent has been the development of markets and commercial transactions before the development of political forms of governance. Throughout European history, many cases of commercial developments before the formations of States were seen, which was the case of the Hanseatic League in the $14^{\text {th }}$ to $17^{\text {th }}$ centuries, the Italian cities, and the Dutch Republic. European history has always shown a tendency for market development to have precedence over political-development itself. ${ }^{26}$ The European Integration followed this European tendency with the political integration using economic integration as an instrument for its development throughout the following decades. $^{27}$

The rise of Information and Communication Technologies has been characterized by a similar phenomenon with consumerism and business electronic transactions development in the networked new technologies currently gaining an enhanced position, or the new sparking phenomenon of social networks having a bigger influence and projection of citizens socialization and interactivity on the inter-connected online cyber-space, while there is a slower development of publicinstitutional forms of cyber-connectivity with the citizens.

The following European developments, regarding forms of e-Government and e-Democracy were characterised by a more democratic strategy, while the American strategies are more focused on the technological aspects. After all, the European citizen has a core value on the European project, ever since the 1976 Tindemans' report established the need of the European project to be more than a simple market integration, making the European model of e-Governance and e-Democracy to be more focused and based on the citizen. There is also the fact, as it was stated on the 2003 Communication from the Commission to the Council on the Role of e-Governance for Europe's Future, that the public sector plays a very important role in Europe's social and economic model by supporting high levels of welfare for citizens, ensuring socio-economic cohesion and supporting the functioning of a competitive market environment. ${ }^{28}$ This sheer importance leads to the particular importance for the use of these new technologies to improve the citizen's general life.

The European Union has been characterised for establishing its own form of sovereignty in the Cyberspace, with the constant regulation of many elements of Cyberspace, establishing its own borders on the Cyberspace. These new developments have led to many challenges regarding how the Internet is regulated,

\footnotetext{
${ }^{26}$ See Paul Kapteyn, The Stateless Market: The European Dilemma of Integration and Civilization (London: Routledge, 1996), 9-17.

${ }^{27}$ See Pedro Madeira Froufe and José Caramelo Gomes, "Mercado Interno e Concorrência", in Direito da União Europeia: Elementos de Direito e Políticas da União, coord. Alessandra Silveira, Mariana Canotilho and Pedro Madeira Froufe (Coimbra: Almedina, 2016), 450-457.

${ }^{28}$ See the Introduction on the Communication from the Commission to the Council, the European Parliament, the European Economic and Social Committee and the Committee of the Regions on the Role of e-Government for Europe's Future, $\operatorname{COM}(2003) / 567 /$ final.
} 
the development of e-Government and e-Democracy lead to a necessity of a minimal regulation concerning their interoperability. These regulations, themselves, are a controversial matter, considering the special way networks tend to function and the need for balance between all the fundamental rights associated with the use of these technologies with freedom of expression and association, often clashing with other rights and public interests. The North-American and European's different approaches towards these issues reflects how delicate and complex they are. ${ }^{29}$

European citizenship, in this case, is important. Being a citizenship of rights, associated with the European Political Space and identity, being not-bounded by nationality ${ }^{30}$, sharing some traits as the common user on cyberspace, its further developments could mean an increased integration on the European cyberspace, crucial for the development of the Digital Single Market and e-Democracy.

\subsection{Interoperability and the pathway to a European e-Democracy}

The European Union approach on e-Government goes back to 1994 with the Bangemann Report stating that Information and Communication Technologies imply more efficient, transparent and responsive public services at lower cost, while bringing governments and administrations closer to citizens. Recommending, therefore, the establishment of a trans-European public administration network for providing effective and less expensive information interchange between Member State public administrations. This network would subsequently be extended to connect the public administrations and the European citizens, by lowering costs and improving relations between public administrations and European citizens, which were the two goals singled out in the report.

In 1999, the European Parliament and the Council of Ministers decided on the establishment of trans-European telematic networks between Member State administrations and the European institutions.

E-Democracy was mentioned in European documents in 1998, 4 years after the Bangemann report, in a background paper for the Conference of the Information Society Forum of the European Commission. ${ }^{31}$ In 2000, the first steps were taken towards e-participation and e-commerce, with the Presidency assuring the need to shift to a digital, knowledge-based economy, prompted by new goods and services, to develop growth, competitiveness and jobs. ${ }^{32}$

The European Union, itself, recognized its democratic short-comings and the need for the use of the potential of Information and Communication Technologies, in the 2001 White Paper on European Governance. The White Paper stated the need for the Union to communicate more actively with the general public on European issues; that there needs to be a stronger interaction with regional and local governments and civil society, stating that Information and Communication Technologies have an important role in facilitating such communication and that 'Europa' will be re-

\footnotetext{
${ }^{29}$ For a deeper understanding regarding these issues, see Alexandre Libório Dias Pereira, Direitos de Autor e Liberdade de Informação (Coimbra: Almedina, 2008), 334-347.

${ }^{30}$ See Alessandra Silveira, "Cidadania Europeia e Direitos Fundamentais", In Direito da União Europeia: Elementos de Direito e Politicas da União, coord. Alessandra Silveira, Mariana Canotilho and Pedro Madeira Froufe. (Coimbra: Almedina, 2016), 22-29.

${ }^{31}$ See Tuna Baskoy, "The European Union and e-democracy: Interactive Policy-Making (IPM)", International Journal of Eletronic Democracy 1(2) (2009): 220-221.

32 See the Lisbon European Council 23 and 24 March 2000 Presidency conclusions, accessed on 16/06/2018, on: http://www.europarl.europa.eu/summits/lis1_en.htm.
} 
designed as an interactive platform for information, feedback and debate. ${ }^{33}$

Also worth mentioning is the Communication to the Spring European Council in Stockholm from the Commission, regarding the eEurope 2002 initiative, its impacts and priorities, and where it was established in the development of an informationbased society. It analysed the Internet access in many European Member States, already showing some developments, although the regional disparities and the tendency for networks to be concentrated on Central Europe was stated. The eEurope 2002 initiative was launched with the objective of increasing Internet connectivity in Europe and to open up all the communications networks to competition, stimulating the use of Information and Communication Technologies and accelerating e-Commerce. ${ }^{34}$ The liberalisation of the telecommunications market was the European Union's main strategy, as well as the introduction of e-learning and e-working skills.

Regarding e-Government, the Communication emphasized the need for European Union institutions and national public administrations to make an effort to use information technology to develop efficient services for European citizens and business. ${ }^{35}$

The eEurope initiative was launched because Information Communications Technologies could enhance democratic participation. Alongside theseinitiatives, there was also the Interactive Policy Making (IPM), which aimed to improve governance by using the Internet to collect and analyse reactions of citizens and enterprises across the European Union Member States, by helping the Administrations and European Union institutions to understand the needs of citizens and enterprises better, thanks to web-based technologies. ${ }^{36}$

The Interchange of Data between Administrations, mostly known as IDA programme, between 1995 and 1999, with the legal basis being Decision 95/468/ EC, helped establish an interoperability between Member States, the early efforts of which were concentrated on the merging of the technological dimension of the single European market. When the feasibility of exchanging information was the driving motivation of this phase, it was then followed by the IDA II programme, defined by Decision 1719/1999/EC, between 1999 and 2003, which further developed this interoperability. These programmes harmonized with the promotion of e-Government, in the beginning of the new millennium. ${ }^{37}$

The eEurope 2002 initiative was then reviewed and followed by the eEurope 2005 initiative with its focus being the stimulation of services, applications and content that create new markets and reduce costs and eventually increase productivity throughout the economy, developing content, services and applications and rolling out the underlying infrastructure being predominantly up to the market. By making use of the new technological developments, especially with broadband technology, with the

\footnotetext{
${ }^{33}$ See Ruth Wodak and Scott Wright, "The European Union in Cyberspace Multilingual Democratic Participation in a virtual public sphere?”, Journal of Language and Politics 5(2) (2006): 251-252.

${ }^{34}$ See the information on eEurope 2002 initiative, accessed on 16/06/2018, on: https:/ / eur-lex.europa. eu/legal-content/EN/TXT/HTML/?uri=LEGISSUM:124226a\&from=PT.

35 See the Communication from the Commission to the Council and European Parliament, $\operatorname{COM}(2001) / 140 /$ final.

${ }^{36}$ See the information on the Interactive Policy Making initiative, accessed on 16/06/2018, on: http:/ / ec.europa.eu/idabc/en/document/6541/5927.html.

${ }^{37}$ For a deeper understanding regarding the developments of Interoperability, see J. Ignacio Criado, "Interoperability of eGovernment for Building Intergovernmental Integration in the European Union”, Social Science Computer Review 30(1) (2012): 41-44.
} 
2005 goals being the existence of modern online public services, e-Government, e-learning services, e-health services, a dynamic and business environment was created and, as an enabler for these, widespread availability of broadband access at competitive prices, throughout the European Union space. ${ }^{38}$

The IDA II programme was also converted into the Interoperable Delivery of European eGovernment Services to public Administrations, Businesses and Citizens (IDABC programme) with Decision 2004/387/EC, encompassing, many types of innovation being developed. The IDABC programme took a multilevel governance perspective of the interoperability of eGovernment into consideration, including regional and local administrations, as a prerequisite for pan-European service implementation in various Member States. ${ }^{39}$

The eEurope 2005 initiative was also followed by the i2010 Strategy, with its aim being the development of a Single European Space with the even further development of technologies and infrastructures, as well as Digital Convergence, requiring devices, platforms, and services to interoperate, in addition to trustworthy, secure, and reliable Information and Communication Technologies.

These technologies are also highlighted as a form of improving the citizens lives, with the i2010 Strategy recognizing three ways of doing it by making sure that Information and Communication Technologies benefit all citizens; making public services better, more cost effective and more accessible; and improving quality of life. $^{40}$

The "i" being for "an Internal Market in information services, for investment in ICT research and innovation and for inclusion and a better quality of life". ${ }^{41}$

The next developments with the European Union e-Government projects came after the Malmö declaration, in 2009. Considering the economic, social and environmental problems, e-Government was recognized as an important enabler to deliver European-wide policy goals across different sectors, from justice to social security, to trading business services and beyond, it also emphasized a common culture of collaboration regarding e-Government. The principles of Good Administration being highlighted as central on this promoted culture.

This declaration shaped the Policy priorities for 2015, which where:

- Citizens and businesses are empowered by eGovernment services designed around users' needs and developed in collaboration with third parties, as well as by increased access to public information, strengthened transparency and effective means for involvement of stakeholders in the policy process;

- Mobility in the Single Market is reinforced by seamless eGovernment services for the setting up and running of a business and for studying, working, residing and retiring anywhere in the European Union;

\footnotetext{
${ }^{38}$ See the "Communication from the Commission to the Council, the European Parliament, the Economic and Social Committee and the Committee of the Regions - eEurope 2005: An information society for all - An Action Plan to be presented in view of the Sevilla European Council", $\operatorname{COM}(2002) / 0263 /$ final.

${ }^{39}$ See J. Ignacio Criado, Interoperability of eGovernment for Building Intergovernmental Integration..., 44-45.

${ }^{40}$ See the "Communication from the Commission to the Council, the European Parliament, the European Economic and Social Committee and the Committee of the Regions - "i2010 - A European Information Society for growth and employment", $\operatorname{COM}(2005) / 0229 /$ final.

${ }^{41}$ In accordance to the words of the Commissioner Viviane Reding. See Claudio Feijóo, José Luis Gómez-Barroso and Edvins Karnitis, "More than twenty years of European policy for the development of the information society”, Netcom 21(1)(2) (2007): 13.
} 
- Efficiency and effectiveness is enabled by a constant effort to use eGovernment to reduce the administrative burden, improve organisational processes and promote a sustainable low-carbon economy;

- The implementation of the policy priorities is made possible by appropriate key enablers and legal and technical preconditions.

As well as shared objectives of citizens and business being empowered by effective cross-border e-Government Services, with the invitation of third parties to collaborate on its developments, the European Commission was then invited to take appropriate measures to support the objectives of the declaration. ${ }^{42}$

The European Commission established a Digital Agenda for Europe that sets eGovernment within a comprehensive set of measures aimed at exploiting the benefits of information and communication technologies across Europe. ${ }^{43}$ The Commission also defined the aims of online availability of key cross-border services online, enabling entrepreneurs to set up and run a business anywhere in Europe independently of their original location, and allowing citizens to study, work, reside and retire anywhere in the European Union, by 2015. The goal of having $50 \%$ of European Union citizens and $80 \%$ of enterprises using eGovernment services by that year was also set. The need for cross-border services and user empowerment was also emphasized, with the coordination by the European institutions.

The access to non-personal public-sector information was also highlighted, alongside the improvement of transparency, and the development of 'seamless' services for entrepreneurs to set up and run a business anywhere in Europe and allowing individuals to study, work, reside, receive health care and retire anywhere in the European Union.

Some pre-conditions to the development of e-Government were also defined with one of them being the development of interoperability in its many dimensions, like the legal and organisational one, some key enablers like Electronic identification technologies and innovative technical approaches, such as clouds of public services and service-oriented architecture to build open, flexible and collaborative eGovernment services while at the same time lowering Information and Communication Technologies costs. ${ }^{44}$

These goals were linked with the Interoperability Solutions for European Public Administrations, also known as ISA programme with Decision 922/2009/EC on interoperability solutions for European public administrations further developing the various dimensions on the creation and development of interoperability projects. ${ }^{45}$

Most of the goals were reached in 2015, especially concerning Internet coverage and some e-Government developments. ${ }^{46}$

\footnotetext{
${ }^{42}$ See the Malmö Declaration, accessed on 18/06/2018, on: https:/ / ec.europa.eu/digital-single-mar$\mathrm{ket} / \mathrm{sites} /$ digital-agenda/files/ministerial-declaration-on-egovernment-malmo.pdf.

${ }^{43}$ See the "Communication from the Commission to the European Parliament, the Council, the European Economic and Social Committee and the Committee of Regions - A Digital Agenda for Europe", $\operatorname{COM}(2010) / 245 /$ final.

${ }^{44}$ See the "Communication from the Commission to the European Parliament, Council, the European Economic and Social Committee and the Committee of the Regions - The European eGovernment Action Plan 2011-2015 Harnessing ICT to promote smart, sustainable \& innovative Government", $\operatorname{COM}(2010) / 743 /$ final.

${ }^{45}$ See J. Ignacio Criado, Interoperability of eGovernment for Building Intergovernmental Integration..., 46.

${ }^{46}$ See the 2015 Scoreboard, accessed on 17/06/2018, on: https:/ / ec.europa.eu/digital-single-market/ en/news/digital-agenda-scoreboard-2015-most-targets-reached-time-has-come-lift-digital-borders.
} 


\subsection{The problems and challenges for a citizen-centred European e-Democracy}

The development of e-Governance and interoperability in the European institutions, however, despite the achievements, is still limited regarding a more dynamic development of e-Democracy, considering its view as a more active engagement between citizens and their governments through platforms. This requires some empowerment of the citizens to increase their bilateral dialogue with the institutions. ${ }^{47}$

It is worth noting that some recent events have shown some of the risks and impacts Internet and Informatic and Communication Technologies can have with the sudden surge of populism and the Fake News phenomenon, as well as the possibility of the massive and automatic use of these technologies for misinformation aimed at manipulating democratic results and public opinion. ${ }^{48}$ This use of technology can promote a new form of politics characterised by impulsiveness and spontaneity, as well as a rebellious development of it, the latest years have shown some nationalist pressure $^{49}$, leading to some unpredictability on the political world. The development of the Internet communities seems to spark some hostilities between social groups and counter-culture development, as it was noted on the 2016 United States of America Presidential election. ${ }^{50}$

The link between the technological development and the latest populist wave is apparent. Populism can be said to be a mutation of representative democracy, which also comes from a partisan crisis with the progressive erosion of the long-term identities on which the Parties legitimisation were founded. The digital development also created a new form of populism that links the communications to populism. ${ }^{51}$

As we have mentioned, online platforms and communities have shown to have a dissociative effect on the common person, with the average user having a different life online and offline, as well as different expressions and social interactions, depending on the community.

However, in the European Union's context, with the citizen being at the centre of its integration, we believe that a further development of the citizen is essential to tackle these issues. Historically, the adaptation to new technological realities and their problems is not a new phenomenon and as we head to a $21^{\text {st }}$ century online Marketplace of information, Social Networks and new forms of communication, it could be said that the Truth might emerge from its competition with falsehood, albeit the technologies are showing new complexities and hardships. However, the search for information and the truth is always dependent on a community and its citizens. ${ }^{52}$

The citizens empowerment and development are also crucial for a democratic

\footnotetext{
${ }^{47}$ See Julie Freeman and Sharna Quirke, Understanding E-Democracy..., 149.

${ }^{48}$ See Pedro Verdelho, Democracia e tecnologias da informação..., 114-116.

${ }^{49}$ See Pedro Madeira Froufe, "O insustentável peso democrático do populismo: deambulações em torno da União Europeia, de olhos postos em Donald Trump”, in UNIO E-book Volume I - Workshops CEDU 2016, coord. Alessandra Silveira (Braga: Centro de Estudos em Direito da União Europeia, 2017), 301-311.

${ }^{50}$ See Rita de Sousa Costa and Tiago Sérgio Cabral, "The European Union's existential crisis: current challenges from populism to Donald Trump”, UNIO - EU Law Journal 4(1) (2018): 10-11.

${ }^{51}$ For a deeper understanding, see Emiliana De Blasio and Michele Sorice, "Populism between direct democracy and the technological myth", accessed on 21/06/2018, on: https://www.nature.com/ articles/s41599-018-0067-y.

${ }^{52}$ See Rui Vieira, "Reclaiming the Truth: the role of European citizens on countering fake news", accessed on 21/06/2018, on: https:/ / officialblogofunio.com/2017/11/29/reclaiming-the-truth-therole-of-european-citizens-on-countering-fake-news/.
} 
development in these new realities. Considering the democratic deficit and the feeling of non-inclusion and non-representation, a development of e-Democracy could help make up for these issues and help EU citizens and its institutions to bond, as well as to ease up some social tension that is often generated with the development of well-intentioned measures like affirmative action ${ }^{53}$, while promoting a more informed, interactive and balanced representative pluralism. The same technologies used to develop populism can also have the potential to develop a healthier form of interactive democracy, with the European Union being the perfect Post-Modern political construction to develop the first steps.

The further developments of the European Digital Single Market and the arrangements for a further wider range of interoperability mechanisms, the Commission, in 2017, defined the Operative Single Market as perhaps the most important challenge the EU faces today in terms of securing its future competitiveness in the world, with the concern for a digital impact on public services. This interoperability and its further developments have been increased with the ISA $^{2}$ programme revised in 2015, under Decision (EU) No. 2015/2240. The ISA ${ }^{2}$ programme is centred on interoperability solutions and common frameworks for European Public Administrations, business and citizens, allowing an increased interaction between Public Administrations, being of particular importance for the development of e-Government. ${ }^{54}$

These e-Government developments are aimed at the improvement of the democratic process and the strengthening of public participation in decision-making and developing multi-centres of democracy. The Internet can be used for citizens to control their governments. In this sense, it is essential for an interoperability development that allows bilateral and multi-lateral, and interactive, forms of information and eliminates obscure procedures. Improving the quality of online public platforms is also crucial. Some developments and studies are also being made with the possibility of e-Vote, despite the concerns with security. ${ }^{55}$

The fact that the European Union is also a federative post nation-state form of political structuration with its own citizenship that goes beyond the classical national limitations of it, allows for new potential in e-Government and e-Democracy developments of the European Union and its core democratic principles in the $21^{\text {st }}$ century, with the Digital Single Market and interoperability being the way forward, albeit the need for a new focus on the citizen and its role in the formation of an "e-European Union".

\footnotetext{
${ }^{53}$ See Thomas Sowell, Affirmative Action Around the World: An Empirical Study (New Haven: Yale University Press, 2004), 3-71.

${ }^{54}$ See Joana Covelo de Abreu, "Digital Single Market under EU political and constitutional calling: European electronic agenda's impact on interoperability solutions", UNIO - EU Law Journal 3(1) (2017): 123-129.

55 See Mariagrazia Forcella, "E-Democracy: Strategies and New Horizons for the European Union Policies", Journal of E-Government 3(2) (2006): 99-105.
} 